\title{
Transnational Hauntings, Hungry Ghosts: Malaysian Chinese Domestic Gothic Fiction
}

\author{
Anita Harris Satkunananthan \\ University Kebangsaan Malaysia, Selangor, Malaysia
}

\begin{abstract}
Yangsze Choo's The Ghost Bride, which was a finalist for the 2014 Mythopoeic Awards, has recently enjoyed renewed success owing to the Netflix serial based on its premise. The novel takes place in a liminal world populated by Chinese ghosts, Gods and demons. Cassandra Khaw's short story "Some Breakable Things", on the other hand, provides a painful and intimate look at loss and bereavement while utilising the Hungry Ghost as a metaphor. A postcolonial feminist reading of Derrida's theory of hauntology will be applied to my construction and coining of a Malaysian Chinese Domestic Gothic to interrogate and contextualize the hybrid and transnational nature of these texts, which are a palimpsest of Western Gothic traditions and diasporic Chinese funerary customs. The texts' re-creation and re-visioning of these traditional beliefs and customs display the interstitial dilemma of transnational travellers and diasporic individuals who have to constantly negotiate between consent, autonomy and inherited nostalgia. This article will interrogate these narrative palimpsests to unearth how these tales could provide an answer to the problematics of consent inherent in Derridean hauntology.
\end{abstract}

Keywords: Derrida, Hauntology, Postcolonial Gothic, Malaysian Chinese, Geocriticism, Hungry Ghost

\section{Introduction}

In this article I connect specific Malaysian Chinese customs, beliefs and folklore related to the rites of death and the afterlife, with the physical and spiritual embodiments of a Malaysian Chinese home and its customs as depicted in Yangsze Choo's The Ghost Bride (2013) and Cassandra Khaw's "Some Breakable Things" (2016), using Jacques Derrida's theory of hauntology. I categorize these works as "Malaysian Chinese Domestic Gothic". In considering the Malaysian Chinese Domestic Gothic, it is important to connect these diasporic associations with cultural traditions. It is equally important to examine the ways in which the Malaysian Chinese Domestic Gothic is hybrid and the way in which Malaysian Chinese religious beliefs are tied with regional politics. My postcolonial feminist framework employs Derrida's notion of hauntology on the chosen texts in order to interrogate what I categorize as the "Malaysian Chinese Domestic Gothic". I utilize this framework to question the problematics of consent 


\section{SARE, Vol. 57, Issue 1 | 2020}

and filial imperatives in both Choo's novel and Khaw's short story. In so doing, I contend that literary spatial considerations are inherently hauntological because of the spectres of memory implicit within the texts. My use of the term "Malaysian Chinese Domestic Gothic" requires an exploration of what may be categorized as the Domestic Gothic, and how it is distinct within a Malaysian Chinese perspective. Pursuant to my discussion, I will be exploring a number of Malaysian Chinese beliefs in relation to the selected works, focusing on the rites of death and of the afterlife; more specifically, I am concerned with the rituals and traditions of Qing Ming (Cheng Beng) and the Hungry Ghost Festival, which arise from both Buddhist and Taoist traditions but which may have their origin in mainland Chinese religions. The Festival itself exists across the global Chinese diaspora, but has a specific set of significances for the Malaysian Chinese diasporic community, inclusive of the Peranakan Chinese community.

A woman-identified body is political. How that body connects to space is political. Both Choo's and Khaw's constructions of the Hungry Ghosts speak of a conflict in embodying the postcolonial woman-identified body in space and in time, and how that connects to the problematics of consent. I interrogate the ways in which the examined narrative reflects communal anxieties and desires in relation to life after death. Choo's fiction demonstrates the ways in which human characters relate to the dead, how this is reflected in their embodiment (or the lack thereof, given the pervading metaphor of the Hungry Ghost and corporeal dissolution) and how it ties them to their respective traditions, complicated by conflicted transnational associations. Andrew Hock-Soon Ng writes that "ghost stories by women" reclaim "a sense of continuity and tradition that have been relegated to ...the "shadows"" (Interrogating Interstices 156). Continuity and tradition from a postcolonial feminist perspective is therefore important to consider because home becomes a site for ghosts but also a site for contention and negotiation. Sara Ahmed writes of the home that "Home is some-where; it is indeed else-where, but it is also where the subject is going. Home becomes the impossibility and necessity of the subject's future ... rather than the past that binds the subject to a given place" (78). This statement may be connected to the uncanny lineaments of the Domestic Gothic, as exemplified by the buildings within which these hauntological contentions occur.

My postcolonial feminist approach in this article includes a consideration of the different spaces the characters inhabit in the narrative: not just a literal home but the different definitions of home, especially for Li Lan as she travels through a ghostly embodiment of Malacca. This connects to the Domestic Gothic lineaments of the text. For instance, one may 


\section{SARE, Vol. 57, Issue 1 | 2020}

read the Peranakan House in The Ghost Bride as an analogue for the liminal conflicts experienced by the characters in all of the studied texts, while the apartment in Khaw's "Some Breakable Things" also becomes the site for interstitial negotiations with the spectres of the dead. Her narrator is also haunted outside of the confines of her home and the domestic conflicts are therefore externalized. In both instances, the problematics of consent are inherent in the ways in which the protagonist confronts the ghost of her father. These liminal conflicts include motifs depicting funerary rites and the liminal space between life and death, such as the red string and the Hungry Ghost. I therefore identify the most pressing points within these liminal conflicts as being connected to consent.

At the heart of these correspondences between faith, culture and individual feminine choice is a liminal conflict. Choo's much-lauded novel is a variation of the bildungsroman where this conflict comes into play; in this conflict one may discern the struggle to obey and the struggle to retain one's autonomy and right to consent or deny consent. In The Ghost Bride, Li Lan, the protagonist, finds herself in the "afterworld" of her ancestors and the world from which the spirits come in her quest to release herself from being haunted and tormented in her dreams by a ghostly suitor. Ganakumaran Subramaniam and Shanthini Pillai write that a "rhetoric of blame" appears to pervade the collective consciousness of the writers of the Malaysian Chinese diaspora "whose cultural memory of the older country lies entombed with the ghost of the 1969 racial riots and the departure that ensued" (67). More importantly, these memories and associations "inevitably spill over into the diasporic imaginary of the younger generation" (67). I identify this spillage as being implicated in the liminal fracture observable in the fiction of millennial transnational Malaysian Chinese authors, which often finds resolution in supernatural tropes such as the repurposing of the Hungry Ghost. It is most pervasive in the works of Choo and Khaw in relation to Malaysian Chinese beliefs and festivals.

These beliefs are not mere literary devices, but form an important component of Malaysian Chinese customs that are based on Taoist and Buddhist beliefs. For instance, Qing Ming, celebrated early in the Chinese calendar, respects ancestors and the dearly departed through a ritual cleaning of graves. On the other hand, the Hungry Ghost festival coincides with the Harvest Festival on the Chinese Calendar. For an entire month, ghosts are said to roam the liminal boundaries between life and death. Food as well as paper offerings are made for them, the latter burnt so that they will become manifest in the afterlife. They also mark a 


\section{SARE, Vol. 57, Issue 1 | 2020}

communal ritual encompassing the entire month known as Ghost Month. Both periods reflect the connection between the living and the dead.

From Qing Ming to the Hungry Ghost Festival to the rites of funerals, these works of Malaysian Chinese fiction exemplify transnational hauntings from the homeland. I therefore read these ghosts as psychic residues of an association with a Malaysian Chinese lifestyle and this is directly relevant to my hauntological application of a postcolonial feminist method on the category of Malaysian Chinese Domestic Gothic fiction.

\section{The Hungry Ghost in the Malaysian Chinese Cultural Imaginary}

In this section, I provide a background of study to delineate the ways in which the Hungry Ghost is important in the construction of both identity and the sense of the uncanny in both texts. One may argue that the proliferation of Hungry Ghost stories and the spatial element of these stories signify that as a liminal entity the Hungry Ghost heralds the hauntological and uncanny aspect of the Malaysian Chinese Domestic Gothic.

Jasmin Ho and Tan Ai Yeng observe that the Hungry Ghost Festival is a time when "souls from the netherworld pardoned by the Di Guan Da Di (ruler of the Earth) are released to the earthly realms to enjoy a one-month long "vacation"' (par. 2). This month is known as Ghost Month and is host to a slew of beliefs, rituals and superstitions. There are a couple of important points to register regarding the origin of the Hungry Ghost beliefs from Mainland China. Firstly, Phillip E. Bloom, in a detailed analysis of twelfth-century AD Chinese Buddhist Art, writes that "a gaggle of hungry ghosts (Chinese: egui, Sanskrit: preta)" are representatives of "one of the six realms of rebirth in the Buddhist cosmos that are identifiable by their needlethin throats and distended bellies" (309). Bloom's work identifies the place of the Hungry Ghost in Buddhist cosmology. Connected to the origins of the Hungry Ghost, Mike Wilson asserts that when Buddhism came into contact with indigenous belief, those beliefs were incorporated into Buddhism, such as the Bon religion which segmented the world into three realms: "Heaven, consisting of gods and demigods; Earth, consisting of Humans and Animals; and the Underworld, consisting of Hungry Ghosts and Demons" (26). Belief in the Hungry Ghost evolved further when it reached Malaya during colonial times. Ghost month, the seventh lunar month of the Chinese calendar, became an integral method of connection for the Chinese community, and its peak is the Hungry Ghost Festival.

In Malaysia, the Hungry Ghost Festival has been an integral part of the cultivating and evolution of a Malaysian Chinese communal consciousness and will to action. Following from 


\section{SARE, Vol. 57, Issue 1 | 2020}

the collective trauma of the May 13 race riots in Malaysia, the revitalization of the Hungry Ghost Festival became even more important to the Chinese community. Jean Debenardi writes:

Those who led the revitalization of the Hungry Ghosts Festival knit together the diverse street committees into a higher-level organization in order to create a sense of unity and shared purpose, and to propose a solution to fears among the Chinese about their future in Malaysian society. (158)

It is therefore important to understand the socio-political contexts of why the Hungry Ghost Festival traditions, while observed globally, have specific markers, goals and aims within the Malaysian context and why it thus appears in the studied texts. The sense of unity is one that, as with most communities, is not devoid of crosshairs of conflict and transgressions of omissions and commissions, but it is doubly fraught for the transnational and diasporic woman caught between worlds. This liminal state is by its very ontology transgressive, and this is why narratives that enfold both the states of the living and dead are both suggestive and important to consider within the postcolonial feminist hauntological framework that I have constructed for this essay, connected to the proliferation of Hungry Ghosts in The Ghost Bride and in the persistent return of the ghost of the protagonist's father in "Some Breakable Things".

\section{The Architectural Uncanny and the Domestic Gothic}

The Peranakan House is a house that is made out of many elements: English, European, Chinese, Moorish and Malay. As a composite, the Peranakan House represents the hybrid lineaments of Peranakan culture: European, Chinese, and Malay. Andrew Hock-Soon Ng writes that Peranakan Culture is primarily patriarchal, averring that the epitome of the ideal Peranakan woman is "submissive, obedient, silent" ("Malaysian Gothic" 83). This is a paradigm that is disrupted in The Ghost Bride. Ng writes that they are "Chinese whose lineage can be traced back to the Malaccan Sultanate in the fifteenth century" ("Malaysian Gothic" 83). They then "adopted the lifestyles of the local Malay community, transforming, in the process, aspects of their own culture, especially in terms of food and dress" ("Malaysian Gothic" 83). This creates a sort of "cultural affinity" ("Malaysian Gothic" 83). Nevertheless, $\mathrm{Ng}$ avers, this hybrid community remains ethnically Chinese. $\mathrm{Ng}$ connects the text of Shirley Lim's "Haunting" to the Domestic Gothic by reading it against Charlotte Perkins Gilman's The Yellow Wallpaper, because most of a Peranakan woman's life is led indoors ("Malaysian Gothic" 82-83). This is precisely why Li Lan's actions in The Ghost Bride may be seen as 


\section{SARE, Vol. 57, Issue 1 | 2020}

doubly transgressive. She travels outside of her own home both physically and as a spirit without a chaperone, and in so doing manages to reclaim her own destiny.

The uncanny lineaments of space and Peranakan architecture in The Ghost Bride may be connected to Anthony Vidler's concept of the Architectural Uncanny. Vidler comments that the "theme of the uncanny serves to join architectural speculation on the peculiarly unstable nature of "house and home" to more general reflection on the questions of social and individual estrangement, alienation, exile and homelessness" (ix). This he reads as revealing a "disquieting slippage between what seems homely and what is definitely unhomely" (ix-x). Vidler's discussion is important to consider in my construction of a postcolonial feminist hauntological framework specifically designed to understand the ways in which the authors address the connection between the living and the dead, particularly in relation to the collective cultural belief in the Hungry Ghost. Vidler's comment may be read in tandem with Ahmed's discussion of home, in which she says that being transnational requires one to examine "what it means to be at home, to inhabit a particular place, and might call us to question the relationship between identity, belonging and home" (78). She elucidates that a "narrative of homely subjects who have forgotten "the Home" and who are therefore "temporary guests in their place of origin" requires one to examine the notion of home "from the point of view of those who, in leaving home, have become the strangers" (78). Unhomeliness therefore is a heightened response to the transnational condition in which homes are spaces expanded beyond the constraints of a home, and the idea of the Domestic becomes contested. It is unsurprising therefore that the notion of home may be connected to the architectural uncanny in both texts, and the ways in which this sense of the uncanny is intrinsically connected to Derridean hauntology.

\section{Derridean Spectres and the Problematics of Consent}

In this article I focus on the problematics of consent in Choo's The Ghost Bride and Khaw's "Some Breakable Things" and how both texts may be read as a fictive response to the problematics of consent. While neither of these works directly address the Derridean spectre, I argue that the interactions between female protagonist and patriarchal spectres in both stories are both counterpoint and interrogation of the spectre of the ghostly father in Derridean hauntology. The issue of consent is an important aspect of Choo's novel where more than one man seems hell-bent on deciding Li Lan's life for her, and this endangered autonomy crosses 


\section{SARE, Vol. 57, Issue 1 | 2020}

over from the physical realm to the supernatural realm, while in "Some Breakable Things" the father is a persistent horrific intrusion upon the peace and wellbeing of the narrator. My application of Derridean hauntology from a postcolonial feminist perspective is therefore a philosophical and theoretical intervention, aimed at utilizing these texts as an answer to the question inherent in Derrida's texts.

This central metaphor in Derrida's discussion, that of the living receiving the spectre of the father, has been problematized by the feminist critiques of Nancy J. Holland (2001); I have furthered Holland's argument by positioning a feminist hauntology within the context of postcolonial feminism (2018). Holland problematizes the Derridean hauntological framework from a feminist context when she asks "what becomes of the daughter in this hauntology, the daughter for whom both the symbolic and the literal F/fathers, and thus also the duties and debts they engender, are always simply Other, beyond any possible filiation or inheritance?" (65). I extend this contention by situating the problematics of consent within an expanded hauntological framework which considers postcolonial tensions.

The spectre, or revenant, as it comes to haunt the female narrator or protagonist in postcolonial texts is imbued with the kind of complicated guilt that postcolonial women face, implicitly entwined within what Gayatri Spivak calls the "double bind"; it may be implicated in what Spivak calls the "problem of subjectship and agency" and the "call to build" an infrastructure (438). This double bind is an acutely problematic dilemma for the transnational author and is therefore pertinent to consider for women caught in-between the imperatives of culture and lineage as may be seen in the selected texts, related to the ways in which the living invite, invoke and communicate with the dead or the undead.

I situate the spatial imperatives of the Chinese diasporic woman as located within family and tradition against the liminal hauntings that evoke past ties and the tensions between familial duty and the desire for personal choice. These are postcolonial feminine tensions which underscore the feminist interrogation of Derridean hauntology which I have written about before. The main theoretical framework for this article is therefore hauntological in nature. I have constructed a theoretical framework that builds off Derrida's three most relevant texts (Aporias, Spectres of Marx, and Of Hospitality). Unpacking three relevant concepts, I analyse the supernatural limits, transgressions and communication with spectres from a postcolonial feminist perspective and situate these two texts as a counterpoint to these arguments. 


\section{SARE, Vol. 57, Issue 1 | 2020}

Derridean hospitality is related to the ways in which refugees are treated as the "Other" in their host countries. A postcolonial Gothic reading of Ghosts and other spectral entities however equates these entities with the Other, and with the concept of refugees at large. Tied into this consideration is the pressing concern of consent and how the lack thereof impedes female agency. The intimations of the feminine self in considering hospitality emerge particularly in the reading of texts in which hospitality may also be equated with consent.

Because of the partially spatial configurations of this method, I read these tales in tandem with Vidler's work on the Architectural Uncanny. In The Architectural Uncanny, Vidler writes that "architecture reveals the deep structure of the uncanny in a more than analogical way, demonstrating a disquieting slippage between what seems homely and what is definitely unhomely" (ix-x). That slippage may find its correspondences with liminal spaces of the Peranakan House, and how this corresponds with the aporetic slippages in most supernatural and Gothic fiction - the ways in which the human/living narrator confronts or connects to the spectre.

In Aporias, Derrida writes about crossing that ultimate border, of death (8). He says, that the act of entering, the "I enter", involves crossing a threshold, and that "I pass (perao)" sets the traveller on the road or path of "the aporos or of the aporia: the difficult or the impracticable, here the impossible, passage, the refused, denied, or prohibited passage" (8). Of course, the limits between life and death may be inferred to be the "[N]onpassage, which can in fact be something else, the event of a coming or of a future advent ...[that] no longer has the form of the movement that consists in passing, traversing, or transiting” (8).

There is a fluidity in Derrida's discussion of moving across this most liminal and most conflicted of limits. It frames the most important aspect of Aporias for this article: Derrida's discourse concerning the crossing of the "borders" of truth, and about the "general defect" which is necessitated by this border crossing (1). This is a form of transgression, which Bertrand Westphal writes of as being a "transgression" which is a "crossing of a boundary beyond which stretches a marginal space of freedom" (47). Westphal's geocritical perspective of space and boundary-crossing may be mapped onto Derrida's aporetic netherlands. These netherlands incorporate the unknown region of death which Derrida defines as a crossing of borders, delineating this in spatial terms "of territory and of a country" (Aporias 5). The concept of limits and the transgression thereof allows for the spectre to visit the living, and vice versa, as the living seek to communicate with the dead, but this concept has to go hand in hand with 


\section{SARE, Vol. 57, Issue 1 | 2020}

consent as consent is after all part and parcel of the negotiations inherent within hospitality. This communication with the dead is not limited to talking to the ghost of Marx, but includes considering the unknown and how the narrator, or protagonist, or Self relates to the Other. My assertion, therefore, is that these three Derridean texts are deeply connected in considering those epistemological limits within which the in-between operates.

Derrida further expands upon the crossing of borders, specifically related to the "threshold of death" via which we are engaged "toward a certain possibility of the impossible" (Aporias 11). Derrida's theorizing of border crossings delineates that "indivisible line" that connects identity between the known and the unknown (11). In so doing, he draws analogies to customs or police check-posts, the institution, and the idea of hospitality (10-11).

In Aporias, Derrida discusses the tension between the dead and the living. He suggests that the final frontier of death necessitates sympathy and hospitality towards the spirits or ideas which haunt, but this is not always possible and certainly not so when the haunter is a patriarchal force with power and influence over the haunted, as is evidenced in the studied texts. Some of Derrida's thought is expanded in Of Hospitality. The "question of hospitality", Derrida avers, begins where we ask the "foreigner to understand us, to speak our language" and how this may or may not delineate if the "foreigner" would "still be a foreigner" (Dufourmantelle and Derrida 15-16). This loaded question includes what happens if a "foreigner" is "accused in a language he doesn't speak" (16). The concept of home and the Domestic needs to be connected to the idea of migration, of the moment when the home becomes unhomed, as Ahmed has very convincingly argued (80), and this is metaphorized in The Ghost Bride to stunning effect. In this text we see the concept of the Other poised as a guest in one's country, or someone poised on the threshold of what is familiar - the Other in Choo's works may be read as the multiple spectres in the text, and Li Lan herself who becomes the Other.

Specters of Marx is the book most specifically concerned with a Derridean hauntology. The book itself is concerned with the death of Marxist thought in neo-capitalistic times. But what is the spectre? Derrida elucidates that the spectre is a "paradoxical incorporation, the becoming-body, a certain phenomenal and carnal form of the spirit" (5). But it is clear that this revenant that Derrida speaks of is something phenomenological rather than actively supernatural (5). Nevertheless, Derrida employs supernatural metaphors to examine phenomenal states of being; of emotions; of hauntings; of loss. Loss, then, is an integral aspect of human experience, a phenomenal aspect that is tied into space and time. These are the aspects 


\section{SARE, Vol. 57, Issue 1 | 2020}

of hauntology that I find pertinent to the discussion in this essay. What, however, is clear is that the examples look at power relations in both Of Hospitality (the foreigner and the native) and the Father and the son in Specters of Marx. How, then, is this connected to the hybrid and often rebellious women in the texts of transnational diasporic Chinese women writing back to their ghosts and their cultures? I unpack this by examining my expanded hauntological framework in the Malaysian Chinese Domestic Gothic texts in the next two sections.

\section{Otherworldly Cartographies, Hungry Perambulations}

Yangsze Choo is a diasporic Malaysian novelist who has gained much acclaim for The Ghost Bride. Despite the protagonist Li Lan's reluctance and her father's seeming reluctance, they are seduced by the wealth of the Lim matriarch in different ways. Li Lan, the prospective bride for the Lim family's dead son, is invited to the Lim home more than once, and there she is fed Peranakan treats, and is given gifts. Hungry for family and a sense of belonging, Li Lan begins to accept the Lim clan. Li Lan is therefore introduced to the family and attends their gatherings, falling in love along the way with the cousin of her ghostly intended. Li Lan, who is tortured by the ghost of her potential bridegroom, decides to consult a spirit medium to find a way out (Choo 70-72). This action takes Li Lan fully into what I have delineated as a postcolonial feminist hauntological dialectic: when the female protagonist questions the very structures that determine her role in life and the spectres who impose those imperatives. This I read as being transgressive from a hauntological perspective. In travelling to the afterworld, Li Lan discovers the secrets of her family, as well as the truth behind her mother's demise. She is then able to speak with her mother and the ghosts of the Lim family, whose fate seems intertwined with her own.

Prior to her afterworld odyssey, Li Lan is wooed to be a "ghost bride" for the dead son and heir of the affluent Lim family. Li Lan is naturally horrified by the idea but is persuaded by her father to consider it. She introduces the festival of Qing Ming in her narrative as "the festival of the dead", where people would "sweep the graves, honour our ancestors and offer food and incense" (Choo 7). Li Lan notes that the mere thought of "having to pay my respects as the widow to a stranger made me shudder. And what exactly did marrying a ghost entail?" (Choo 7). She is terrified and repulsed by this concept and nowhere in her narrative is there any indication of consent. In her testimony there is a direct confrontation with the notion of the spectre, of connecting to the other side as a supernatural unknown - and this becomes more acute when Li Lan is stalked through dreams by her would-be suitor, Lim Tiam Ching. This is 


\section{SARE, Vol. 57, Issue 1 | 2020}

where the aporetic liminal space of Derrida may be discerned. This aporetic state into which Li Lan is slowly inducted culminates in her odyssey in the Plains of the Dead.

I read this section of The Ghost Bride as being an expanded metaphor for the transnational process of migration and how it relates to the problematics of a Derridean hospitality which I assert is deeply connected to hauntology. In writing about the transnational Malaysian poet Hilary Tham, Khoo et. al. comment that "fraught negotiations of...dissolved cultural identities are never unilateral", and further assert that a form of cultural "translation is required when mediating cultural identities" and boundary crossings (661). This observation regarding translation is relevant in considering the work Derrida does in fleshing out the concept of "hospitality", of that which works between and beyond borders. This Derridean hospitality bears relation to what Ahmed means when she refers to migration as being a condition of being without a fixed home (80). This aspect of Derridean hospitality is particularly important in The Ghost Bride, because Li Lan makes the transition from being haunted in her own home, to being a roaming spirit, untethered from her home and relying upon the hospitality of other Ghosts in an act of metaphorical inversion (Choo 108).

Qing Ming, the festival of the dead, is integral to the plot of the novel as it introduces a fully developed otherworld of the afterlife which allows the reader a glimpse into the complexities of this hybrid, Malaysian-Chinese custom. Choo refers back often to the festival of Qing Ming but it is clear that the events of The Ghost Bride occur during the seventh lunar month of the Chinese calendar; the Double Seven festivities occur shortly before Li Lan embarks on her afterworld odyssey into the alternate version of Malacca inhabited by ghosts, demons, Gods and spirits. Furthermore, the streets of Malacca are thronged by Hungry Ghosts, as Li Lan relates: "Hungry ghosts seemed to appear from all directions, detaching themselves from walls and fluttering out of passageways" (Choo 110). As Li Lan mentions, even as she watched, "two more hungry ghosts appeared behind me" (Choo 110). She is able to see these ghosts because she herself is in spirit form, walking the spirit world while her body lies in a coma.

Li Lan has agency enough to be inimical to the ghost of her intended from the beginning, showing a definite refutation of his presence. But there is, at the heart of the novel, an ontological inversion. In the world of the living, the ghosts are "guests", while in the Afterworld, they are very much the hosts, and it is Li Lan who has to fit into the construct of their world. However, the dynamics of hospitality are not so clear-cut here - the idea of consent and hospitality towards a ghost is problematic because, as a ghost in the world of the living, 


\section{SARE, Vol. 57, Issue 1 | 2020}

Lim Tian Ching is still in a position of power both as a patriarch and a very wealthy one. Giovani Da Col, in his extended discussion on reciprocity and citizenship in the relationship between strangers in the anthropological construction of hospitality, distils Derridean hospitality as the "famous association of hostility and hospitality" (19). Da Col then elucidates upon anthropologies of visiting - a term that is helpful in considering the ways in which Li Lan crosses over thresholds. But the aspect of hostility as depicted by Derrida is also important. Li Lan's hostility towards Lim Tian Ching's interloping in her dreams is crucial in the shaping of her narrative arc - in entering her dreams, Lim Tian Ching robs her of consent, and she reclaims her autonomy by rejecting him with harsh and violent words. Consent therefore is an important component of the hospitality-hostility dialectic.

This power dynamic is clearly oppressive to Li Lan and forms the central struggle in the novel, even as she grows into womanhood by falling in love with two separate men, one of whom is Lim Tian Ching's cousin, while the other is a demigod (Er Lang) (Choo 166). Even as Li Lan goes through the motions of allowing Lim Tian Ching's family to woo her, she refutes him in her dreams as his very presence "had violated the recesses of my soul" (Choo 46). In this refutation one sees the rightfully hostile/inhospitable approach towards the Derridean outsider, who has forced an intimate trespass into her unconscious. But Lim Tian Ching's visits are also a foreshadowing of the inversion that occurs when Li Lan enters the Afterworld after having overdosed herself on the powder the spirit medium gave her (Choo 99).

In the Afterworld, Li Lan discovers secrets about her heritage, namely the pox that consumed her mother and ruined her father's life, by talking to and interrogating the ghost of her mother. Confronting the ghost of one's own mother is not a comfortable endeavour; it is further complicated by underworld rumours that cause Li Lan to believe her mother is the shady second wife of the "old master", who is Lim Tian Ching's "great uncle" (Choo 220). Her mother is, however, Auntie Three (Choo 259), one of the many people who work in the ghostly mansion. The levels of secrets and mysteries behind the death and afterworld life of Li Lan's mother display not just a quiet heroinism but a subtle textual challenge of the patriarchal imperatives underlining Peranakan heritage and culture. Here, I read the Derridean spectre as well as the relationship between the living and the dead, as one confronting the unseen, the ineffable, which inexplicably (as the Dead do in ghost stories) begins to speak back to the subject. In Li Lan's dialogue and interactions with her mother, a slow-burgeoning relationship, which has a deepening understanding, stands as a counterpoint with the other, more aggressive spiritual encounters. 


\section{SARE, Vol. 57, Issue 1 | 2020}

Li Lan's odyssey into the afterlife has some correspondences with Chinese opera for instance, Mulian, which Josh Stenberg describes as "providing a foundational role in the Yulan or Ghost Festival [which is] celebrated throughout the Chinese world" (31). Stenberg describes this opera as "Half-Orpheus, half-Journey to the West", and calls it an "important part of funeral rituals" in the "Hokkien cultural area on the Mainland" and in Taiwan (31). I touch upon the Mulian story because the plot centres on the rescue of the monk Mulian's mother from hell (31) and this has resonances with Li Lan's encountering of her mother in the hellscape of the Lim mansion in the afterworld.

Li Lan, then, is a model of the postcolonial feminist hauntological subject - who interrogates and problematizes ghosts, who understands that an acceptance of and hospitality towards spectres can sometimes mean the erosion of one's own agency and autonomy. She upends the power relations implicit in the relationship between the human subject and the spectre by becoming herself a ghost and a "foreigner" within the surreal landscape of the afterlife. I find in The Ghost Bride, therefore, a satisfying challenge thrown at the head of the Derridean spectre. It is also a good example of how the postcolonial feminine Gothic troubles the markers of Otherness in both literature and philosophy.

\section{Spectral (Un)Familiarities}

Khaw is one of the most recent additions to the growing body of work by millennial Chinese authors. Khaw's works straddle the Gothic of Chinese folklore and superstition as well as Lovecraftian horror. As with Choo and other authors in this corpus, her fiction reflects an uneasy balance between personal myths and the impact of multiple diasporas. In an article for ScifiNow, Khaw speaks about her life as a nomadic author and her connection to her culture. She writes of being from the Chinese diaspora, noting that it colours her Hokkien, and pointing out that her palate is "more adjusted for spice" ("I Didn’t Know" par. 6). She says that her accents are filled with the cadence and rhythm of her "Peranakan forebears" (par. 6). This is a tacit nod to her Peranakan heritage and the ways in which this hybridity informs her fiction. Khaw's writing tends to focus on her liminal state of being as a transnational and nomadic author while grappling with issues of her upbringing. She connects these elements through supernatural tropes from Malaysian Chinese beliefs and culture.

The hungry ghost and the red string re-occur in Khaw's fiction. For instance, "Red String" (2015) tells the tale of an undertaker sent to woo a recently deceased man's widow because her attachment to him was stopping him from moving on. There are also two wildly 


\section{SARE, Vol. 57, Issue 1 | 2020}

differing tales focusing on the Hungry Ghost in her oeuvre. Firstly "Hungry Ghosts" (2016) is a futurist cyberpunk tale that has digitized ghosts as witnesses for the protagonist's performance during the Hungry Ghost Festival (pars. 1-3). Secondly, "Hungry Girls" (2020) is a horror story featuring a film-maker in a ménage à trois with a supernatural lady picked up during the Hungry Ghost Festival. In this article, however, I focus on Khaw's “Some Breakable Things" as being more relevant to my discussion on haunting, and hospitality to the spectre, focusing on the issue of consent. "Some Breakable Things" is a visceral supernatural and semifictional account derived from the protagonist's experience of losing her father, upon which I map a postcolonial feminine hauntology. In this short story, Khaw's protagonist looks at the death of her father through the eyes of Chinese superstition. I read in this story a kind of fraught relationship between father and daughter. The haunting begins thus:

As though to make up for his absence in life, your father's ghost follows you everywhere. Never too close, never near enough to encapsulate in a hug, but never at a distance where you can justifiably ignore the knowledge of his presence. (Khaw "Some Breakable" par. 8)

This directly introduces the spectre of the father as a presence that is not entirely welcome. There is a sense here that consent cannot be negotiated, as he is always trailing after her. Hospitality to this stalking ghost is not an option. He is not welcome in her house but lingers, everywhere; he follows her and harries her. This is an unwelcome spectre who is nonetheless the object of a tortured kind of love. The following section delineates the ways in which this most unhomely visitation follows the protagonist out of the confines of her home into her outer home - that of the city that houses her:

He trails you into supermarkets but not public lavatories, cafes but not changing rooms, forever hovering outside the door, his face a blot of colors runnelling together, recognizable but not necessarily identifiable. (Khaw "Some Breakable" par. 9)

The liminal nature of Khaw's narrative utilizes doorways, stairwells and the living room to make the author's point. This embodiment of the architectural uncanny is made literal in the narrative:

At home, he occupies doorways, both ends of the stairwell, the foot of your bed. You quickly learn that he will leave you alone whenever you sleep on the couch, seemingly repulsed by the suffering his company incited, so you colonize the 


\section{SARE, Vol. 57, Issue 1 | 2020}

living room. A bad back is worth seven hours of bad sleep. (Khaw "Some Breakable" par. 9)

$\mathrm{He}$ is a persistent presence, unlovely and grotesque. He embodies the hungry ghost and there is nothing comforting about him as Khaw's narrative slips into the kind of body horror for which she is famed:

You pointedly ignore his reflection in the laptop screen: his skin is missing, his torso gapes like a mouth, the ribs gleaming teeth-like against the wet mass of his innards. Intestines drool from the base of his breastbone, a spiral of nesting pinks. (Khaw "Some Breakable” par. 25)

This ghastly embodiment of her father exists to strike horror into her; his presence is visceral, unwanted, an ugly memory of past hurts. This problematizes hospitality. Irina Aristakhova writes about the implicit maternal aspect of hospitality as the "intimate (private) or communal (public) welcoming of strangers into one's own house, country or territory" (163). She writes that Derridean conceptions of hospitality could be "renovated as a profound and transformational concept in our understanding of self and other" (163). Aristakhova's distillation and expansion of Derridean hospitality is a timely one as it considers the position of the feminine in a philosophical engagement with the notion of haunting and of spectres in general. I read this distillation as being relevant to the see-saw of emotions in Khaw's protagonist's reaction to the ghost of her father.

This entity is suspected by the protagonist to be a hungry ghost because of his perpetual presence, and presumably because of cultural imperatives. Those cultural imperatives elide consent and feminine autonomy, and trouble the markers. In this abject representation of the patriarch, I see an alternate reading of that idea of being hospitable to the spectral other, the ghost of the father rendered unlovely. The protagonist does online research on the hungry ghost, and unearths a psychological understanding of what hungry ghosts represent to her culture and to herself.: "Hungry ghosts were driven by intense emotional needs in an animalistic way. Hungry ghosts were lessons. Hungry ghosts were victims" (Khaw "Some Breakable" par. 28).

The hungry ghost in Chinese folklore is different in representation from Khaw's very psychological depiction of the protagonist's father. Khaw's language utilizes brutal images of wounds and bruises, displaying a fascination with traumatized physical sites as an analogue for more conventional imagery. These sites of trauma find a cognate in an envisioned afterlife, 


\section{SARE, Vol. 57, Issue 1 | 2020}

seen as grotesque and inimical in Khaw's fictive welstanschauung, and the spectre of the father goes beyond the uncanny to the Kristevan abject. I discern in the tortured relationship between daughter and hungry ghost father, then, another complication of the hospitality equation in the reception of the spectral father. Consent is an important cue particularly in reliving the memories or spectral presences of an abusive parent - and the dialectic between hospitality and hostility is acutely complicated by Khaw's narrative. Hospitality, of a kind, occurs towards the end after the protagonist talks to her mother, after they have hired an exorcist, and the protagonist realizes that she has to confront her ghost with words: "'I love you,' you tell the emptiness, the bruise-black dark. The words sound small and vulnerable in the waiting dark, almost child-like, completely inadequate. The silence eats them whole" (Khaw "Some Breakable" par. 93).

The propitiation or attempt at propitiating the ghost involves a communication, a wish for forgiveness, a kind of reconciliation that is that of the subject addressing the Other, of trying to come to terms with a painful past. In this story, this propitiation is of an uneasy and difficult kind because the protagonist feels beaten down by an insistent presence into forcing the words out, because there is no respite from the force that follows her everywhere, no sign that there is an easy resolution or if this hungry patriarchal ghost will finally leave her in the end.

\section{Conclusion: Interrogating Ghosts, Settling Old Debts}

Upon analyzing these works of fiction, I return to problematizing the notion of the patriarchal spectre as exemplified in my expanded discussion of Derridean hauntology in connection to not just Spectres of Marx but also Aporias and Of Hospitality. As is evident in these tales by Choo and Khaw, often the ghosts these women confront are those of their mothers, or grandmothers - who are also part of a patriarchal culture. However, where the ghosts are male, they are often intrusive, abusive and frequently rob the female protagonists of consent. This finding resulted in my adapting and interrogating the Derridean notion of hospitality as directly related to the problematics of feminine consent and autonomy against the strictures of traditions that span the provinces of the living and the dead.

I have found that the gender of these ghosts does not change the fact that the spectre is still patriarchal. From a Malaysian Chinese perspective, the propitiation and honouring of dead ancestors and parents therefore connects to patriarchal imperatives. It is clear that both Choo and Khaw have their own contentions towards the traditional imperatives. This feeds into 


\section{SARE, Vol. 57, Issue $1 \mid 2020$}

their non-traditional female characters who challenge, who fight back and who re-construct the traditional norms of their cultures.

\section{Works Cited}

Ahmed, Sara. Strange Encounters: Embodied Others in Postcoloniality. London: Routledge, 2000.

Aristakhova, Irina. "Hospitality and the Maternal”. Hypatia 27 (1): pp.163-181, 2012.

Bloom, Phillip E. "Ghosts in the Mists: The Visual and the Visualized in Chinese

Buddhist Art, ca. 1178. The Art Bulletin 98 (3): pp.297-320, 2016.

Choo, Yangsze. Ghost Bride. London: Hot Key Books, 2013.

Da Col, Giovanni. The H-Factor of Anthropology. L'Homme 231/232: pp.13-40, 2019.

Debernardi, Jean. Penang: Rites of Belonging in a Malaysian Chinese Community. 2009.

Derrida, Jacques. Specters of Marx. London: Routledge Classics, 1994.

--- . Aporias. Stanford: Stanford U P, 1993.

Dufourmantelle, Anne and Jacques Derrida. Of Hospitality: Anne Dufourmantelle Invites Jacques Derrida to Respond. Stanford: Stanford UP, 2000.

Harris Satkunananthan, Anita. 'Haunts and Specters in Chimamanda Ngozi Adichie's Biafran (Re)visitations', 3L: The Southeast Asian Journal of English Language Studies, 24 (4): pp 185-198, 2018.

Ho, Jasmin and Tan Ai Yeng. "Hungry Ghost Festival Facts". The Star. 20 August 2016. https://www.thestar.com.my/metro/community/2016/08/20/hungry-ghost-festivalfacts-practices-and-meaning-behind-monthlong-celebrations-by-taoists-and-buddh

Holland, Nancy J, 'The Death of the Other/Father: A Feminist Reading of Derrida', Hypatia, 16 (1): pp 64-71, 2001.

Khaw. Cassandra. "Red String”. Fantastic Stories of the Imagination. 2015.

---. "Some Breakable Things". The Dark 16. 2016. https://thedarkmagazine.com/somebreakable-things/

---. "Hungry Ghosts". Nature 539. 2016. https://www.nature.com/articles/539602a

---. “I Didn’t Know I was Exotic until You Told Me”. SciFiNow. 2017.

https://www.scifinow.co.uk/blog/cassandra-khaw-i-didnt-know-i-was-exotic-untilyou-told-me/

---. "Hungry Girls" in Ellen Datlow, ed. Final Cuts. New York: Anchor

Books, 2020. Excerpted in: https://crimereads.com/excerpt-hungry-girls/. 


\section{SARE, Vol. 57, Issue 1 | 2020}

Khoo Siow See, Ruzy Suliza Hashim, Raihanah M. M. "Negotiating Hyphenated Identities in the Selected Poems of Hilary Tham”. International Journal of Academic Research in Business \& Social Sciences 8 (8): pp. 659-673, 2018.

$\mathrm{Ng}$, Andrew Hock-Soon. "Malaysian Gothic: The Motif of Haunting in K.S. Maniam's "Haunting the Tiger" and Shirley Lim's "Haunting"”. Mosaic, An Interdisciplinary Critical Journal, 39(2): pp. 75-87, 2006.

$\mathrm{Ng}$, Andrew Hock-Soon, Interrogating Interstices: Gothic Aesthetics in Postcolonial Asian and Asian American Literature. Berlin: Peter Lang, 2007.

Spivak, Gayatri Chakravorthy, An Aesthetic Education in The Era of Globalization. Harvard: Harvard U P, 2012.

Subramaniam, Gunakumaran and Shanthini Pillai. "Reconciling Malaysian Chinese Identity: Multiple Passages to Nationhood". SARE: Southeast Asian Review of English, 48 (1): pp. 56-74, 2008.

Stenberg, Josh. "Rescuing Mulian's Mother in the Xi Era: Reviving Ritual Xiqu in Contemporary Fujian”. Asian Theatre Journal 36 (1): pp. 28-48, 2019.

Vidler, Anthony. The Architectural Uncanny. Massachussets: MIT Press, 1992.

Westphal, Bertrand. Geocriticism: Real and Fictional Spaces. London: Palgrave Macmillan, 2011.

Wilson, Mike. "Schisms, Murder, and Hungry Ghosts in Shangra La". CrossCurrents 49 (1): pp. 25-38, 1999. 